\title{
Applicability of book value to estimate property of Polish forest management units
}

\author{
Krzysztof Adamowicz ${ }^{\circledR}$, Magdalena Gwiazdowicz ${ }^{1}$, Piotr Szczypa ${ }^{2}$ \\ ${ }^{1}$ Poznań University of Life Sciences, Faculty of Forestry, Wojska Polskiego 71C, 60-625 Poznań, Poland, \\ e-mail: adamowic@up.poznan.pl \\ ${ }^{2}$ State University of Applied Sciences in Konin, Przyjaźni 1, 62-510 Konin, Poland
}

\section{Abstract}

At present, various solutions are proposed for the appraisal of forest land and stands. Recently an important problem concerning business information is connected with the valuation of assets of individual forest districts. In practice, numerous methods are used to estimate the property of enterprises. However, there are no universal methods to estimate the value of an enterprise. One of these practically applicable methods is the book value method (BVM). In view of the above, it was decided to analyse the applicability of this method to valuate the property of forest districts. Based on the conducted case study and the discussion of results, it was found that the original BV method may not be used to appraise the property of forest districts. The primary justification for rejection of this method in the valuation of forest district property results was from the lack of financial balance information on the value of forest land and stands. As a result, the value of a forest district calculated using the BVM is underestimated. A lesser but significant effect on the estimated value of forest districts is also observed for cash flows related with the Forest Fund. In the case of net contributors, the estimated value of forest districts is overestimated and that of net beneficiaries is underestimated.

\section{KeY WORDS}

Forestry economics, forestry accounting, balance, property appraisal, value of enterprise

\section{INTRODUCTION}

Presently, information is one of the greatest assets of any economic entity. In recent years, we have been observing increased demand for information supporting the decision making process (Kędzior 2005; Adamowicz 2012). Bengston (1994) claimed that currently, rapid and crucial changes take place, affecting the demand for information on the valuation of forest, its functions and property of forest units. Such informa- tion is of practical value, since it may be used when managing forest units.

Forest management has to be adapted to the diverse and changing conditions of the broadly understood forest economy. Reporting and financial analysis are integral components (subsystems) of the accounting information system and enterprise management. In turn, accounting is the basic tool in the processing of information concerning phenomena and economic processes, thanks to the used appropriate methods and apparatus, 
providing insight into these phenomena and processes, their complexity, causes and interactions. As a result, it facilitates the selection of adequate variants of economically justified activities and provides grounds for improved control, planning and other management tools, thus enhancing the efficiency of economic activities of enterprises and improving their financial standing. As a result, it serves a supplementary function in relation to management (Walczak 2003).

Following the guidelines resulting from scientific discussion held in 2016 at a conference on forestry economics concerning the 'Valuation of forest property and its functional components', principles are being developed in Poland on the valuation of forest management units. Various solutions are proposed in relation to the valuation of land and stands. Recently, a crucial problem concerning business information is also connected with the valuation of an enterprise (forest district). In view of the specific character of forest economy comprising numerous non-economic functions (e.g., ecological, conservation, educational, recreational functions, etc.), as well as the fact that the State Forests National Forest Holding manages forests owned by the State Treasury, we need to search for an adequate method to valuate the forestry activities. This should, on the one hand, provide support for the decision making process, and on the other hand, supply reliable information to the public on the quality of this management activity. For this reason, the valuation of a forest management unit needs to be understood as a process in the appraisal of the forest unit and its assets, as well as the economic effects of decisions, ensuring such a quality standard that would provide the informed parties with a potential to assess the effects of past actions and select the most advantageous decision variant in the future (Steiger 2008; Dunal 2014). One of the sources of such information comprises data on the value of an enterprise or management unit.

Asset-based methods are the most popular valuation methods applied in companies (management units) and at the same time, historically, the oldest. They were the first tools applied in valuation of economic entities. For this reason, it is assumed here that property, that is, assets less borrowed capital, is the basis for the determination of the enterprise value. Thus, the result of valuation is referred to as property value. Value of an enterprise is estimated based on the balance prepared for the day of valuation. Both in literature on the subject and in practice, we may find the following types of property valuation methods: the book value method (BVM), the replacement value method and the realisable value (liquidation) method.

All the methods of enterprise valuation published in literature (e.g., Kamela-Sowińska, 1993; Nita 2007; Jaki 2008) have both advantages and disadvantages. It must be remembered that there are no universal methods to estimate the value of enterprises. The BVM is one of the simplest and practically applicable methods. In view of the above, it was decided to analyse the applicability of this method in the valuation of property of a forest district.

\section{Material AND MEthodS}

The primary scientific aim of this study was to assess the applicability of BVM to valuate the property of forest districts and to present a subjective opinion of the authors on the practical value of this method in forestry. Since in BVM, the determination of value for assets and liabilities results from the currently binding regulations of the financial balance law, the first stage of the study consisted of an analysis of balance sheets of a forest district in order to identify the potential availability of required source data to be used in the analysed method. This study was based on the quality structured observation, consisting of the analysis of financial documentation of a forest district from the years 1995-2015. The primary source of data was provided by balance sheets of the forest district.

A case study was conducted in order to collect information on the applicability and suitability of BVM in forestry practice to valuate property of forest districts. This analysis consisted of an attempt to use this method to valuate the property of one of the forest districts in the Regional Directorate of the State Forests in Szczecin.

The results of activities were composed of two parts: the explanandum and the explanans. The explanandum comprised what was explained. The potential applicability of the BVM to valuate property of forest districts was explained. In view of the fact that to estimate the value of a unit in BVM, the balance sheet is required; in the process of deduction and scientific 
induction, the balance sheet data accumulated within ex analyses were used.

Following the methodological assumptions, the valuation of property of a forest district was performed based on the determination of balance sheet value of equity capital of the analysed forest district. This value was determined from the difference of balance sheet value of assets and the balance sheet value of liabilities:

$$
B V=A-P O
$$

where:

$B V$ - value of an enterprise estimated using the BVM,

$A$ - balance sheet value of assets,

$P O$ - balance sheet value of liabilities.

This stage of the study provided identification of potential advantages and disadvantages connected with the use of this method in forestry practice, which needs to be treated as the explanans of the research process.

\section{Results AND Discussion}

Following the methodological assumptions, a review of balance sheets of the forest district from the years 1995-2015 was conducted in order to identify potential applicability of these data in the book value method. It was found that the State Forests National Forest Holding, as any other economic unit subjected to the regulations of accounting law, adopted its model of financial accounting system as an obligatory accounting subsystem. In view of the current organisational structure of the State Forests National Forest Holding, the majority of current obligations related to accounting are imposed on forest districts. Although there is one accounting system, not all economic units maintain identical levels of accounting. Additionally, the specific character of forest economy and the monopolist position on the market of timber production and sale result in accounting in forest districts being unique in comparison to that of other economic units (Szczypa 2016, Adamowicz et al. 2017). This specific characteristic causes no organisation problems in the access to source data required for the practical application of the method in forestry. Based on the analysis of balance sheets of the investigated forest district, empirical data were obtained on the balance sheet value of assets and the balance sheet value of liabilities. On this basis, the balance sheet value of equity capital could be determined. Based on the accumulated source materials, an effective estimate of property of the forest district was performed using the BVM. This analysis showed that balance sheet value of assets in the analysed forest district ranged from approx. 4 million PLN (1995) to slightly below 11 million PLN (2011). In turn, the balance sheet value of liabilities was from approx. 0.6 million PLN (1995) to approx. 4.6 million PLN (Tab. 1). It also needs to be stressed that in the investigated period, the balance sheet value of both assets and liabilities increased.

When valuating the book value of forest district using the BVM, it was found that generally the value of property in the analysed management unit increased. From 1995 from approx. 3.5 million PLN, it grew to approx. 7.5 million PLN in 2012. In the following years, a marked decrease was observed in the value of the forest district to approx. 5.5 million PLN in 2015 (Tab. 1).

Table 1. Balance sheet value of assets, balance sheet value of liabilities and value of forest district property estimated using the book value method

\begin{tabular}{|c|c|c|c|}
\hline Year & $\begin{array}{c}\text { Balance sheet } \\
\text { value of assets }\end{array}$ & $\begin{array}{c}\text { Balance } \\
\text { sheet value } \\
\text { of liabilities }\end{array}$ & BV \\
\hline 1995 & 4015789.58 & 564731.25 & 3451058.33 \\
\hline 1996 & 4262816.77 & 600833.95 & 3661982.82 \\
\hline 1997 & 4461494.46 & 789315.26 & 3672179.20 \\
\hline 1998 & 4466941.34 & 866513.14 & 3600428.20 \\
\hline 1999 & 4936637.65 & 913700.89 & 4022936.76 \\
\hline 2000 & 5380053.93 & 919176.61 & 4460877.00 \\
\hline 2001 & 5159200.74 & 791649.86 & 4367551.00 \\
\hline 2002 & 6193073.68 & 743904.10 & 5449170.00 \\
\hline 2003 & 6752640.92 & 1394054.81 & 5358586.00 \\
\hline 2005 & 6380940.48 & 1476592.01 & 4904348.47 \\
\hline 2006 & 7212152.39 & 1766424.06 & 5445728.00 \\
\hline 2007 & 7499408.00 & 1868099.44 & 5631309.00 \\
\hline 2008 & 8299661.22 & 2129573.04 & 6170088.00 \\
\hline 2009 & 7791079.88 & 1645859.84 & 6145220.00 \\
\hline 2010 & 8771325.55 & 2540238.23 & 6231087.00 \\
\hline 2011 & 10949588.29 & 3472191.47 & 7477397.00 \\
\hline 2012 & 10794931.09 & 3223837.04 & 7571094.05 \\
\hline 2014 & 10847901.54 & 4308188.28 & 6539713.00 \\
\hline 2015 & 10075668.98 & 4580498.45 & 5495171.00 \\
\hline
\end{tabular}


To a considerable extent, this resulted from the sale of undepreciated buildings to forest wardens. It needs to be remembered that in Poland, they are frequently sold with maximum possible deduction, amounting to $95 \%$ (i.e., $3 \%$ for the years of residence and $6 \%$ for the years of employment in the State Forests); additionally, with the possibility to pay in 60 low-interest instalments. When analysing the results, we need to remember that this fact is reflected in the balance sheet of the forest district and this affects its book value. Although, as it was reported by Trzcinski and Kaczmarczyk (2010), in the decade of 1999-2008, the State Forests National Forest Holding allocated 37281 buildings for sale; the process of sale for redundant real property was not completed. As a result, the sale of real property will continue to influence the balance sheet components, that is, the fixed assets, and this will be reflected in the book value calculated using the BVM.

Another problem influencing the valuation of forest district performed using the BVM is the funding system of forest districts. It needs to be remembered that in practice, we may find two basic forms of financial system in forestry. One of them, closely related to the state budget, consists of financing the forest economy from the state budget. It is characteristic of such public legal entities as the state budget-financed entities and enterprises and found, for example, in Germany and Switzerland. This system is characterised by a considerable share of the state budget in the redistribution of financial resources. Thus, it is bureaucratic, slow to act and generates additional costs, for example, connected with settlements; while it is also sensitive to the actions of various pressure groups (Fajferek 1999). In Poland, another solution is implemented. Although self-financing has been typical of commercialised forest units practically since 1924, the Polish forestry is operating based on this system (Szramka et al. 2016). It is obvious that forest management units realise their tasks under diverse natural and economic conditions. This has an impact on the financial aspects of the executed forest management (Marszałek 1987; Białczyk and Molendowski 2006; Adamowicz et al. 2016a, 2016b; Gostołek and Adamowicz 2016; Kożuch and Adamowicz 2016). This means that units operating under advantageous conditions obtain additional (surplus) economic effects such as differential land rent; while units operating under less advantageous conditions have no such effects
(Blaug 1994) and as a consequence, may face problems with self-financing. Additionally, the financing of forest economy is influenced by the fluctuating situation of the timber market (Ratajczak 2011; Adamowicz and Noga 2014; Adamowicz et al. 2016c). In practice, this means that some administrative units are not able to generate funds required for self-financing. In such a case, one of the basic tasks of the financial system of a forest management unit is to modify cash flows between operating units, facilitating timely execution of planned economic activities in all the units, regardless of the conditions, in which they are operating.

In this case, in order to ensure financial stability of the forest district, the forest fund (FF) was established within the framework of financial structures within the State Forests National Forest Holding. It is first of all a mechanism for redistribution of funds coming from profitable districts (generating financial surplus) to units suffering losses. This opinion is shared by Kołodziejczyk (2004); Hołuj (2006); Piekutin and Gruchała (2006); Dyduch and Kożuch (2007); Bartniczak (2009); Janeczko and Mandziuk (2010); Dyduch (2012); Adamowicz and Szczypa (2014); and Barczak and Kowalewska (2014). Definitely, the Forest Fund is an organisational form of financial management of the State Forests National Forest Holding (Dyduch 2012) and as such, it is a significant element affecting specific items in the balance sheet.

Adamowicz et al. (2017) showed that redistribution of means within FF influences selected items in the balance sheet of a forest district. Additionally, opposite effects of the FF appropriation on balance sheet components are observed in the case of forest districts being net contributors and beneficiaries. A positive balance value from intra-sector settlements results in a proportional increase in the balance sheet totals, as both shortterm investments for assets and the financial result (net profit) for liabilities increase by an identical value. A negative balance value from intra-sector settlements causes no changes in the balance sheet totals, while the structure of financing within liabilities is changed, since the net financial result is reduced by an identical value as the increase in short-term liabilities. As a result, these changes have an effect on the BVM value of the forest district established by BVM. In the case of net contributors, this value will be over valuated, and for beneficiaries, it will be under valuated. 
Problems presented above influence the results obtained when using the analysed method in practice. In the opinion of the authors, the greatest problem in valuation of property of a forest district using BVM is connected with the fact that the value of stands and forest land is reflected to a limited extent in balance sheets of forest district. However, the forest districts conduct valuations and records for all the forests they manage. These are non-accounting records at the application of valuation prepared for the report on assets of the State Treasury, to date prepared for the Minister of Treasury. Financial books register only the purchased or exchanged land (forest) and only the value of these forests is shown in the balance sheet. Value of forest sensu stricto (valuated stand excluding land) is not presented as a separate value. As a result the value of land, treated as forest, is not presented in the balance sheet in a comprehensive manner and concerns only a small proportion of forests managed by the forest districts.

Additionally, no definite legislative solutions are binding in Poland, which would facilitate a reliable determination of stand value. So far, the forestry economics specialists have developed several stand valuation methods, which may be classified into three groups, namely static, empirical and stand table methods (Chapman and Meyer 1947; Davis 1966; Zhinkan 1995; Zając and Świętojański 2002). The situation is additionally complicated due to the fact that both groups of the above-mentioned functions (productive and social) may be and in reality are performed by all forested areas. However, the benefits of one type provided by a forest generally require a compromise in relation to its other functions. The extent of this compromise is determined by the character of the technical and economic interdependencies between individual functions of the forest (Płotkowski 2008).

In the opinions of the authors, the value of stands and land in the accounting system kept in forest districts should be comprehensively recorded and presented in a balance sheet, which would facilitate effective valuation of book value in the valuation of a forest district. Such a solution may be implemented in the light of binding regulations, only in the case when for a given property component valuation principles are available, applicable in practice and not disturbing commonly accepted principles and functions of the accounting system. However, an analysis of the 'Accounting principles (policy) in the State Forests National Forest Holding' does not provide information on what valuations need to be applied in relation to forest, particularly forest sensu stricto. The document only indicates valuation parameters for fixed assets divided in terms of the manner (cause) for an increase in the SFNFH property (e.g., purchase, generation within the unit or acquisition based on an administrative decision). We focused on the section concerning the valuation of fixed assets in view of the identification of forest in the Acts on forests as land (art. 3 of the Act on forests). The direct adoption of the definition of forest from that Act for the purpose of accounting system in the State Forests National Forest Holding generates specific problems or even results in certain limitations. In the accounting practice in that holding, the principles of valuation are indicated for all fixed assets depending on the manner of their generation. This also concerns land. However, specific regulations indicate at the same time that valuation of land is performed only for the land purchased or acquired by exchange.

The Act on Accounting specifies that assets are such components, the value for which may be reliably determined, and thus, we face a problem of how to valuate forests following the assets valuation principles given in the Act on Accounting in the case of natural forests or forests planted 70 or 100 years ago or even earlier. The parameters and principles of valuation given in the Act on Accounting are not adapted to specific situations concerning a component of property such as forests managed by the State Forests National Forest Holding, constituting an inseparable whole with land.

Following the guidelines in the case when there are no applicable regulations in the Act on Accounting, the State Forests National Forest Holding should apply solutions ensuring the National Accounting Standards (NAS) or International Accounting Standards (IAS). Unfortunately, there are no standards within NAS referring to the valuation of forest property. Similarly, none of the standards within IAS regulates the valuation principles for forest stands and the standards most similar to the subject of this study, that is, MSR IAS Agriculture and IAS 16 Property, plant and equipment, are not applicable in the forest district practice. In authors' opinion, the only solution facilitating effective incorporation of stands and land in the balance sheet of a forest district, and the application of BVM to valu- 
ate the property of a forest district is to develop a new National Accounting Standard for forestry or a selected problem of valuation of forests (forest property).

\section{Concluding Remarks}

Value management of any enterprise, including forest districts, is considered to be a concept adequately reflecting the need to determine the objectives of enterprise operations, as well as promoting integration of objectives for its managers, owners and administrators. It indicates the need to maximise value for all stakeholders, and for this reason, it is considered to be universal. In forest economics, realised based on the objectives given in the Act of 28 September 1991 on Forests (with later amendments), the maximisation of profits in an enterprise is not an overriding goal of operations. However, it does not exclude the attempt to maximise the value of forest districts, particularly in view of their economic and non-economic functions. Information on the value of a forest district is also an element combining the corporate strategy with the generated financial results. Value management is a philosophy of enterprise management, in view of which the operations of company and management processes focus on the maximisation of its value from the point of view of interests of its owners and involved capital. This concept assumes undertaking such strategic, operating and investment decisions in the enterprise. This in turn will facilitate the achievement of the primary goal of the company, which is increasing its value. Modification of value is one of the strategies adopted when running economic activity, while the introduction of specific management processes is required for its implementation (Jaki 2008; Szczepankowski 2007; Wiśniewski 2011). All these elements indicate the essential role of information on forest district value. In view of the above, adequate methods need to be found that either in their pure or modified form could be applied in valuation of forest districts serving several non-economic functions apart from their commercial operations. As a result, the activity in the realisation of forest economy is unique in character, and for this reason, several economic methods applicable in other sectors may not be used in forestry. In the opinion of the authors this statement refers to the analysed valuation method. Based on the conducted investigations, it was found that:

1. The BVM in the original form may not be applied in the appraisal of forest district property.

2. The primary methodological problem in terms of the implications to the obtained results is connected with a lack of information in the balance sheet on the value of forest land and stands. As a consequence, the value of forest district calculated using the BVM is underestimated.

3. A lesser, but still significant effect on the estimated value of the forest district is also observed for cash flows related with the Forest Fund. In the case of net contributors, the estimated value of the forest district is overestimated, while for the beneficiaries it is underestimated.

4. In view of growing importance of business information concerning the value of enterprises, including forest districts, further research needs to be conducted in order to indicate an appropriate valuation method for forest districts.

\section{References}

Adamowicz K. 2012. Evaluation of changes in forest economy conducted by Polish State Forests (Państwowe Gospodarstwo Leśne Lasy Państwowe) in the aspect of raw wood sale in Poland. Rozprawy Naukowe 441. Uniwersytet Przyrodniczy w Poznaniu, Poznań.

Adamowicz K., Dyrcz A., Szczypa P., Zydroń A., Szramka H. 2017. The effect of the forest special purpose fund on values of individual items in the balance sheet of a forest management unit. Sylwan.

Adamowicz K., Gostołek R., Jaszczak R., Szczypa P., Szramka H. 2016a. Evaluating the impact of silvicultural treatments and forest habitat type on the cost of timber harvest in cleanings and thinnings. Sylwan, 160 (12), 993-1002.

Adamowicz K., Kożuch A., Jaszczak R. 2016b. Application of an ex post analysis for the preparation of the economic annex to the forest management plan. Sylwan, 160 (11), 883-892.

Adamowicz K., Noga T. 2014. Multivariate analysis of bankruptcy in companies in the wood sector. Sylwan, 158 (9), 643-650. 
Adamowicz K., Szramka H., Starosta-Grala M., Szczypa P. 2016c. Export and import of timber in selected member states of the European Union. Sylwan, 160 (3), 179-186.

Adamowicz K., Szczypa P. 2014. The Possibilities of Management Accounting Use in National Forests. Prace Naukowe Uniwersytetu Ekonomicznego we Wrocławiu, 344 Rachunkowość a Controlling, $13-24$.

Barczak A., Kowalewska E. 2014. Financing sources of tasks in the field of environmental protection in Poland - an overview of applied solutions. Prawo Budżetowe Państwa i Samorzqdu, 2 (1), 37-58.

Bartniczak B. 2009. Agricultural land protection fund and forest fund as ecological funds. Equilibrium, 3(2), 89-97.

Bengston D. 1994. Changing forest values and ecosystem management. Society \& Natural Resources 7 (6): 515-533

Białczyk W., Molendowski F. 2006. Labour consumption and costs of forest work for selected type of forest site. Inżynieria Rolnicza, 2, 111-118.

Blaug M. 1994. Teoria ekonomii. Ujęcie retrospektywne. PWN, Warszawa.

Dunal P. 2014. The company valuation market methods. Acta Universitiatis Lodziensis Folia Oeconomica, 2 (300), 61-73.

Dyduch J. 2012. An analysis and assessment of the functioning of the forestry fund in 2002-2010. Zeszyty Naukowe/Polskie Towarzystwo Ekonomiczne, 13, 309-318.

Dyduch J., Kożuch M. 2007. Use of the forest fund of the agricultural land protection fund in financing environmental projects in Poland. Zeszyty Naukowe Akademii Ekonomicznej w Krakowie, 732, 75-94.

Fajferek A. 1999. Polityka ekonomiczna. Wydawnictwo Akademii Ekonomicznej w Krakowie.

Gostołek R., Adamowicz K. 2016. The effect of forest site type on thinning type ratio. Acta Scientiarum Polonorum Silvarum Colendarum Ratio et Industria Lignaria, 15 (3), 169-174.

Hołuj A. 2006. Theoretical bases of environmental protection in Poland. Folia Oeconomica Bochniensia, 4, 29-45.

Jaki A. 2008. Wycena i kształtowanie wartości przedsiębiorstwa. Oficyna Ekonomiczna Grupa Wolters Kluwer, Warszawa.
Janeczko K., Mandziuk A. 2010. Expenses on natural forest education and recreational development in LKP Bialowieża forest. Studia i Materiały Centrum Edukacji Przyrodniczo-Leśnej, 12 (1), 54-62.

Kamela-Sowińska A. 1993. Wycena przedsiębiorstw i ich mienia w warunkach inflacji. Zeszyty Naukowe, Seria 2, Prace Doktorskie i Habilitacyjne/Akademia Ekonomiczna w Poznaniu, 114.

Kędzior Z. 2005. Badania rynku - metody zastosowania. PWE, Warszawa.

Kołodziejczyk M. 2004. Fundusz Leśny. Las Polski, 12, $20-21$.

Kożuch A., Adamowicz K. 2016. Effect of costs incurred on the development of non-productive forest functions on the economic situation in forest districts in the Regional Directorate of the State Forests in Krakow. Sylwan, 160 (12), 1010-1020.

Marszałek T. 1987. Ekonomiczne problemy gospodarki leśnej. Wydawnictwo SGGW-AR, Warszawa.

Nita B. 2007. Metody wyceny i kształtowania wartości przedsiębiorstwa. Polskie Wydawnictwo Ekonomiczne, Warszawa.

Piekutin J., Gruchała A. 2006. The role of the Forestry Fund in State Forests financial system. Sylwan, 2, $37-45$.

Plotkowski L. 2008. Economical forest functions evaluation or economic elements of sustainable forest management. Studia i Materiały Centrum Edukacji Przyrodniczo-Leśnej, 10.3 (19), 252-272.

Ratajczak E. 2011. Popyt na drewno w Polsce - zmiany strukturalne oraz możliwości zaspokojenia. In: Strategia rozwoju lasów i leśnictwa w Polsce do roku 2030 (eds.: A. Sawicki, J. Szewczykiewicz, G. Szujecka). IBL, Warszawa, 151-166.

Steiger F. 2008. The validity of company valuation using Discounted Cash Flow methods. Seminar Paper, European Business School, Cambridge.

Szczepankowski P. 2007 Wycena i zarządzanie wartością przedsiębiorstwa. Wydawnictwo Naukowe PWN, Warszawa.

Szczypa P. 2016. Forest districts accounting - current and future status in the light of the current state of science and knowledge in the field of accounting. Acta Scientiarum Polonorum Silvarum Colendarum Ratio et Industria Lignaria, 15 (2), 97-103. 
Szramka H., Starosta-Grala M., Adamowicz K. 2016. Forestry in sectoral economic development in Poland. Sylwan, 160 (5), 416-423.

Trzcinski G., Kaczmarczyk M. 2010. The functioning of the building infrastructure after modification organization in the 'State Forests' National Forest Holding. Technika Rolnicza Ogrodnicza Leśna, 3, 21-25.
Walczak M. 2003. Analiza finansowa w zarządzaniu przedsiębiorstwem. Difin, Warszawa.

Waśniewski P. 2011. Value based management as an instrument of business activity steering. Studia i Prace Wydziału Nauk Ekonomicznych i Zarzadzania, 21, 117-134.

Zając S., Świętojański A. 2002. Podstawy metodyczne wyceny lasu. Sylwan, 3, 5-20. 